







https://doi.org/10.25007/ajnu.v9n2a762

\title{
التنظيم القانوني لتعويض ضحايا النزاعات المسلحة غير الدولية
}

(دراسة تحليلة مقارية)

ק.م هزار جال ياسين، قسم القانون، جامعة نوروز (طالب دكتوراه جامعة سوران (بحث مستل))، أقليم كوردستان، العراق

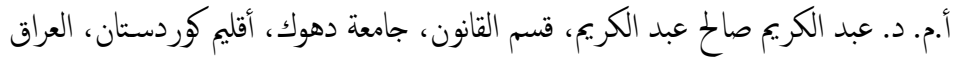

مع تزايد النزاعات المسلحة غير الدولية وانتشارها في الآونة الأخيرة في (العراق و سوريا واليمن وليبيا)، تهتم الحكومات فقط بسن القوانين لملاحقة الجناة وماكتمه باجراءات سريعة دون أن تأخذ بنظر الاعتبار موضوع تعويض الضحايا من جراء هذه الاعحال، فقد أصدرت الدولة عدة تشريعات لتعويض اوليك الضحايا او ورثتهم، ومن بين تلك التشريعات امر بملس الوزراء التشريعي العراقي رقز (10) لسنة 2004


بتعويض المتضررين جراء العمليات الحربية والاخطاء العسكرية والعمليات الارهابية، الوان هذه تعد قواعد عامة وغير كافية وثبت جزهها في تعويض الضحايا لسبب عدم تحديد مصادر تمويل هذا القانون إضافة لوجود ثغرات فهيا فيا يتعلق بكيفية تقدير التعويض وعناصره.

الكلمات المفتاحية: الضحية، النزاعات المسلحة غير الدولة، التعويض.



الضرر. ويرى بعض من الفقهاء أن مبدأ المسؤولية أصبح غير قادر على ضان المماية الفعالة للإفراد، ومن أجل تجنب لهذا العجز ، ظهرت الحاجة إلى نظام ثكميلي لمبدأ المسؤولية يقف جنباً إلى جنب معه، وقد تم ذلك من خلال تطوير وسائل الضمان المالي والمتثثلة بفكرة تعويض الضحايا وحاية حقوقهم وفقاً للقوانين الخاصة ضد أضرار



فهل يعتبر التعويض الذي تقدمه الدولة للضحية بسبب النزاعات المسلحة أو الاعمال الارهابية منحة أم حق؟ وجواباً عن هذا السؤال، نقول إن الدولة ملزمة بحاية المواطنين وغير هم من المتمين على أراضيها من خطر تعرضهم لحالات طارئة أو لحوادث حروب ونزاعات، وما القانون اله كثف لها من الناحية السياسية. ومن ثم يكون التعويض المقابل عنها حقاً شخصياً للضحية لا منحة مقدمة اليه.

\section{1 أهمية البحث وسبب اختياره}

تكمن أهمية الدراسة في الوقوف على تعويض كل شخص طبيعي أصابه ضرر جراء النزاعات المسلحة غير الدولية، وتحديد الضرر وجسامته وأسس النعويض عنه، وكيفية
تعتبر ظاهرة النزاعات المسلحة والعمليات الأرهابية واحدة من أكثر الظواهر شيوعاءفي العالم في الأونة الاخيرة'، وخاصة في دول الشرق الوسط، وأكثر ما يشغل بال الدول والمؤسسات الأمنية، ولكن للأسف إن جل التفكير في الوقت الحاضر ينصب على كيفية مكافة أنشطة الجماعات المسلحة والقضاء عليها دون النظر للضحايا، والاسباب الكمنة وراء تعاظم واتساع هذه العمليات التي تتسم بخصوصية تميزها عن سائر الافعال الأخرى غير المثروعة، سواء من حيث خطورة الأضرار المترتبة عليها أو نوعية الضحية. إذ ينجم عن هذه الأعال قتل العشرات من الابرياء يومياً، والتي تتميز بالعنف الشديد، فضلاً عن انها خلقت حالة من الهلع والرعب والخنسائر البشرية والمادية الكبيرة، كما أنها دمرت البنى الاجتاعية والاقتصادية، ولاسيا إن هذه العمليات خلفت وراءها عدداً كيبراً من الايتام والارامل والمعوقين ، مما ترك أثراً خطير للغاية، خاصة مع التطور الهائل في تكنولوجيا الأسلحة والمعدات العسكرية والحربية، حيث إزدادت المخاطر بشكل كير فتحولت الرغبة في المماية المى حاجة ملّحة لها وفقا لمبدأ المسؤولية والتي تلزم كل من تسبب بععله الخاطىء ضرراً لغيره بتعويض ذلك 




التشريعات التشريع الفرنسي إذ دخلت فرنسا الحرب العالميتين الأولى والثانية وبالنظر لكثرة الحوادث التي تزكنها هذه الحروب، فقد أصدر المشرع الفرنسي قانون 17 نيسان 1919 والخاص بتعويض السكان المدنيين عما لحقهم من اضرار جراء هذه الحروب وخخلفاتها، وكذلك قام المشرع بإصدار أول تشريع يعاجل قضية تعويضات للمتضررين من أعمال العنف ومن ضمنها النزاعات الداخلية والأعال الإرهابية وهو القانون رقّ 77 الصادر في 3 كانون الوول 1977، ويبرز في هذا القانون أنه جعل تعويض الأضرار التي تنشأ عن جرائم العنف2 مسألة اجتاعية وقد انغكس هذا القانون على قانون صندوق ضان ضحايا الإرهاب الذي صدر بعد عام19863. وحدد هذا القانون عدداً من الشروط للتعويض، بما في ذلك أن يكون الضرر جسدياً أو أدى إلى الوفاة أو العجز الكلي أو الجزئي لمدة تزيد عن شهر4، شريطة أن يكون


الأضرار 5. ويمنح القانون الحق في الاستماع إلى طلبات التعويض إلى لجنة تتخذ شكل . محكمة مدنية في مقر كل محكمة إبتدائية، تتألف من إثنين من قاضيين وعضو ثالث يمثل مصالح الضحايا، ، وتسمى هذه اللجنة " لجنة تعويض ضحايا الجريمة" (CIVI) و تكون جلساتها سرية، و من حق الضحية الإستعانة بمام وتقديم الشهود و الإستعانة بالخبراء و تقديم كل ما يساعد على إثبات حقه في النعويض ك.6. ولايمكن للضحية المطالبة لدى اللجنة المختصة بالتعويض إلا إذا استحال عليه الحصول على التعويض من المتسبب، كما أن اللجنة لا تلزم بالتعويض ما إذا كان الخطأ قد نسب إلى الضحية، أو ساهم في وقوع الضرر، وقد صرح القانون أن أساس الدولة في الالتزام بالتعويض هو التضامن الاجتاعي مع ضحايا الجرائ، ومن ثم لا يشكل ذلك اعترافاً بمسؤولية الدولة في مواجحة الضحايا7. وذهب البعض من الفقهاء أن القانون الصادر في 3 كنون الثاني لسنة 1977 قد وضع لتعويض الاضرار الجسدية الناشئة عن جرائم العنف، اذا لم يخطر على بال المشرع وقت نفاذ هذا القانون إنه يمتد ليشمل تعويض الاضرار النامة عن النزاعات المسلحة غير الدولية والجرائم الارهابية، بما تخلفه من أضرار جاعية غير محددة وجسيمة، بجيث أن القانون لايسري إلا على ما وضع من أجله، فلا يجب شد نصوص القانون عنوة لتنطبق على النزاعات المسلحة الداخلية و الاعكال الارهابية التي لم يوضع القانون من



المطالبة به، ومعالجة القصور التشريعي الموجود في قانون تعويض المتضررين جراء العمليات الحربية والاخطاء العسكرية والعمليات الارهابية لسنة 2009 المعدل.


سنحاول من خلال بكثنا أن نجد الإجابة على التساؤلات الأتية: - ما مدى قيام المسؤولية المدنية للدولة عن تعويض ضحايا النزاعات المسلحة في


- ماهي أهم الاسس القانونية التي تستند عليها المسؤولية المدنية للدولة عن تعويض ضحايا النزاعات المسلحة في التشريعات المدنية المقارنة؟ - ماهو نطاق تعويض ضحايا النزاعات المسلحة غير الدولية؟ - ماهي مصادر تعويض ضحايا النزاعات المسلحة غير الدولية؟

4.1 نطاق البحث

إن الإطار الموضوعي للمحاور التي ستعالجها دراستنا يدور حول دراسة الحلول التشريعية المقارنة والفقتهية والقضائية لضان حصول ضحايا النزاعات المسلحة على حقهم في التعويض، والخروج بتوصيات لغرض تقويم وتصويب موقف المثرع في معالجة مشكلة التعويض عن الاضرار من جراء النزاعات المسلحة غبر الدولية، 5.1 سنتمد في دراستنا على المنهج التحليلي والمقارن في بحثنا هذا، من خلال تحليل موقف التشريعات من الموضوع والمقارنة بينها. 6.1

ستناول موضوع بكثنا في مبحثين، حيث سنخصص المبحث الاول لبيان موقف المشرع الفرنسي من تعويض ضحايا النزاعات المسلحة غير الدولية في فرنسا، أما المبحث الثاني فسيكون لموقف المشرع العراقي من تعويض ضحايا النزاعات المسلحة غير الدولية، ونختم بحثنا بأهم النتائج والتوصيات.

\section{2. المبحث الاول: تعويض ضحايا الثزاعات المسلحة غير الدولية في فرنسا}

بسبب تعرض الدول الى حروب أو كوارث أو مخاطر ناجمة عن بعض الجرائم يأتي المشرع ويتصدى لتلك الخخاطر ويبدأ في سن القوانين التي تعاج أثارها، ومن تلك 




وحتى نتيين ما إذا كان هذا القانون يقدم حاية كافية لنعويض الاضرار الناشئة عن النزاعات المسلحة الداخلية، لابد لنا أن نذك شروط التزام الدولة بالتعويض، ونطاق التعويض وفقاً لهذا القانون. 1.1.2 الفرع الاول: شروط التزام الدولة بالثعويض

يتضح من نص المادة (92) سالفة الذكر، أن المشرع الفرنسي تطلب توافر بعض الشروط حتى تقوم المسؤولية المدنية للدولة بالتعويض، وتتمثل هذه الشروط فيا يلي:

أولاً: أن يكون الضرر ناشئاً عن جناية أو جنحة

وفقًا لأحكام المادة (92) من القانون، يجب أن يكون الضرر ناجاً عن جريمة جناية أو جنحة، بغض النظر عما إذاكانت الجريمة من جرائم الاشخاص أو الاموال، وبالنسبة لجرائم الاموال يستوي أن تكون الاموال المعتدي عليها عامة أو خاصة، كما يستوي أن تكون الجريمة مرتكبة ضد شخص طبيعي أو معنوي3.

ثانيا: ارتكاب جناية أو جنحة عن طريق القوة العشوائية أو العنف

يعتبر توافر هذا الشرط ضروري لكي تتحمل الدولة مسؤولية تعويض الضحايا وهذه استناداً إلى حكم المادة (92). إذ يجب أن يكون استخدام القوة العشوائية أو العنف، الذي يشكل جناية أو جنحة، مصدراً للضرر. وحسب رأي بعض من الفقه الفرني، يتميز العنف بالإستخدام غير المثروع للقوة ويفترض وجود مقاومة في موابحة الجماعة المسلحة أو مرتكب الجريمة. أما القوة العشوائية هي عنصراً عمدياً ولا تواجه بمقاومة تجعلها عملاً عنيفاً 14. قيام بعض العال المضربين باحتلال أماكن العمل، إذ التلفيات التي لحقت بالبضائع المخزنة لم تكن ناتجة عن السلب عمداً لهذه البضائع من جانب العال، وائا بسبب توقف العمل أثناء هذا الهمتلال 15.



يجب أن يكون الضرر الذي تلتزم الدولة بتعويضه وفقاً للمادة 92، قد حدث أثناء التجمهر أو التجمع، الأمر الذي يتعين على محكمة الموضوع أن تنظر إلى زمان ومكان الفعل الضار، بجيث إذا ثبت من أوراق الدعوى ومستنداتها أن الظرف الذي حدث فيه الضرر لا يعتبر تجمهاً وتجمعاً، فإن المحكة تقضي برفض دعوى التعويض. لذلك تلك يفترض التجمهر أو التجمع وجود عدد غير محدد من الاشخاص في مكان معين. ولذلك رفضت محكمة النضض الفرنسية الحكم بالتعويض على الدولة استناداً إلى هذه
ونرى أن إحدى أهم مزايا هذا القانون هي أنه جعل من مسؤولية النعويض عن الأضرار التي تسبها جرائم العنف مسألة اجتاعية تهم المجتع بأكمله ، فلا يقتصر أثرها على المتسبب في الضرر وحده وهذا مايتفق مع الاتجاه المعاصر الذي يسير نحو تعدد المدينين بالتعويض.

ولسبب عدم كفاية القانون السابق لعام 1977، أصدر المشرع الفرنسي قانون ك7نون الاول 1983، والذي أقر بشكل صريخ بخلاف القانون السابق في المادة (92) فيه على: "أن الدولة مسؤولة مسؤولية مدنية عن تعويض الأضرار الناشئة عن جرائم العنف بواسطة التجمهر أو التجمعات سواء كانت مسلحة أو غير مسلحة، على أن يشمل التعويض الأضرار الجسدية والمالية". والذي سنتطرق اليه بشيء من التفصيل لاحقاً. وأهم ما يلاحظ أن هذا القانون قد اعترف صراحة بالمسؤولية المدنية للدولة عن تعويض الأضرار التي تلحق بالأفراد من جراء العمليات المسلحة. ولم يكتف المشرع الفرسي بالقانونين أعلاه وإنا أصدر قانون ثالث هو قانون 9 أيلول 1986 بخصوص تعويض الأضرار الناشئة عن جرائم الإرهاب، وقد أنشأ هذا القانون صندوق خاص بتعويض الأضرار البدنية الناجمة عن الحادث الإرهابي، ووفقاً لنص المادة (4) من هذا القانون فإن الأشخاص المستفيدين من التعويض هم ضحايا الجماعات المسلحة والأعال الإرهابية المرتكبة على الإقليم الفرنسي، بغض النظر عن جنسياتهم وكذلك الفرنسيين الذين يتعرضون للارهاب والنزاعات المسلحة خارج فرنساب. 1.2 المطلب الاول: تعويض ضحايا النزاعات المسلحة غير الدولية وفقاً للقانون الفرنسي الصادر في 7 كانون الثاني لسنة 1983

استناداً إلى اعتبارات التضامن الوطني في مواجهة بعض الخخاطر الاجتاعية، أقر المشرع الفرنسي بمسؤولية الدولة عن الاضرار التي لحقت بالأفراد من جراء التجمهرات والتجمعات وفقاً للقانون الصادر في7 كنون الوول لسنة 1983، اذ نصت المادة (92) منه: "على أن الدولة مسؤولة مسؤولية مدنية عن تعويض الأضرار والخسائر الناتجة عن الجنايات والجنح المرتكبة بالقوة العشوائية أو بالعنف بواسطة التجمهر أو التجمعات سواء كانت مسلحة أو غير مسلحة، على أن يشمل التعويض الأضرار الجسدية والمالية.11. وتقوم هذه المسؤولية على أساس اعتبارات التضامن القوي أو الوطني، فلا يشترط لقياما نسبة خطأ ما الى الدولة ولا يكون سبب الضرر راجعاً لأي نشاط صادر عنها"12. - من 




أي صورة من صور الضرر من نطاق تعويض، وبالنالي تسأل الدولة عن كافة الاضرار



النزاعات الداخلية.20 - n

2.2 المطلب الثاني: مدى ملائمة قانون 7 كنون الثاني لسنة 1983 لتعويض الضحايا

عن النزاعات غير المولية

إذا ما توافرت الشروط السابقة، فإن الدولة تكون مسؤولة عن تعويض الاضرار، وذلك بعيداً عن مشاكل المسؤولية بدون خطأ، وبدون حاجة لإثبات أن الضرر نتج عن نشاط الادارة، حيث تلزم الدولة بالتعويض عن جميع الاضرار التي لحتت بالمتضررين، ولايكلف المتضرر باثبات أن الضرر يرجع إلى تقصير أو إهال من جانب


إثبات أن الضرر حدثت بسبب فعل المتضرر .21. ولاشك في أن مسؤولية الدولة عن التعويض يحقق فوائد كيرة للمتضررين، وأهما وجود قوة مالية و تكفل تعويضاً سريعاً وعاجلاً بعيداً عن إعسار الجماعة المسؤولة عن ارنكاب الفعل غير المشروع أو عدم معرفته، حيث أن المشرع لم يتطلب من الضحية أن يرجع أولاً على مرتكب الفعل الضار أو المسؤول مدنياً قبل رجوعه على الدولة، باعتبار أن مسؤولية الدولة ليست



وعلى الرغ من اتساع نطاق النعويض الني تدفعه الدولة إعمالاً لنص المادة 92، إلا انه لايمكن إفادة متضرري النزاعات الداخلية والاعمال الارهابية في جميع الحالات، وذلك نظراً لصعوبة توافر جميع الثروط المنصوص عليها، مثلاً يفترض هذا القانون في التجمهر أو التجمع وجود عدد غير محدد من الاشخاص في مكان، بجيث إذا تخلف هذا الشرط فلا تلزم الدولة بالتعويض استناداً للمادة (92) من هذا القانون. لذلك رفضت محكة النقض الفرني الحكى بالتعويض على الدولة استناداً إلى هذه المسؤولية، إذا كان الضرر نتج عن تصرف لأحد الأفراد تم بطريقة فردية لنحقيق مصاح شخصية وليس عضواً في تجمهر أو تجمع 23. وعلى اثر ذلك قام المشرع بإصدار اكثر من قانون، منها قانون 9 ايلول لسنة 1986 بشأن مكافة الأرهاب والذي أقر مبدأ لنعويض الكمل عن جميع عناصر الأضرار الجسدية الناجمة عن الاعمال المسلحة سواءكانت جسيمة أو خفيفة، ورأى أن العدالة الاجتاعية تقتى المساواة بين ضحايا الاعتداءت على الأشخاص أياً كانت مصدرها. وبعد ذلك قام المشرع الفرسي بإصدار القانون رق 589-90 في 6 تموز1990 بشأن ضحايا الجرائم عدل بمتضاه القانون السابق وأضاف
المسؤولية، إذا كان الضرر نتج عن تصرف لأحد الافراد تم بطريقة فردية لتحقيق مصاح شخصية وليس بإعتباره عضواً في تجمع أو تجمهر 16. وقد توسعت محكمة النقض الفرنسية في إثبات التجمهر أو تجمع، حيث أخذت بإفتزاض أن الاضرار ناتجة عن تجمهر أو تجمع من خلال الوسائل المستخدمة في تنفيذ الجريمة وطبيعة وجسامة الخسائر ، إذ تستنبط المحكة أن الاضرار كانت تحدث بفعل جموعة من الافراد تصرفوا في إطار تجمع أو تجمهر. لذلك يعتبر ان اتجاه محكة النقض الفرنسية السابق خطوة هامة تؤدي إلى تطبيق المادة (92) لتعويض الاضرار الناشئة عن النزاعات المسلحة

وبالاضافة الى ذلك، إذا وقعت النزاعات المسلحة أثناء تجمهر أو تجمع، ينطبق الحكى الوارد في المادة (92)، وتكون الدولة مسؤولة بالتعويض عن جميع الاضرار التي لحتت بالضحايا. وفي هذه الحالة لا يكلف الضحية بإثبات أن الضرر يرجع إلى إهال أو تقصير من جانب الدولة، بحيث لا تستطبع الدولة التخلص من مسؤوليتها إلا بايثبات خطأ الضحية.18.


في حال توافر الشروط التي حددها المشرع في قانون 7 كانون الثاني عام 1983 في المادة (92)، تكون الدولة مسؤولة بتعويض جميع الاضرار، سواء كانت هذه الاضرار جسانية أم مالية، الامر الذي يعني أن نطاق النعويض في هذا القانون يختلف عن نطاق التعويض في القانون الصادر في 3 كانون الثاني عام 1977، إذ أن هذا القانون الاخير قصر النعويض على الاضرار الجسدية الناشئة عن جرائم العنف بشرط أن تكون جسيمة، أما المادة (92) فتلتزم الدولة بالتعويض عن الأضرار الجسدية، أياً كانت درجة جسامتها، والتعويض عن الاضرار المالية مثل تخريب المنشآت وتهدم المباني والحرائق، مما يجعل القانون الصادر في 7 كنون الثاني عام 1983 أوسع نطاقاً في مدى النعويض عن القانون الصادر في 3 كانون الثاني عام 1977 حيث كان قاصراً على تعويض عن الاضرار الجسدية الناشئة عن الاعتداءات أو الجرائم الماسة بالسلامة الجسدية للأفراد، فلم يكن يغطي الأضرار المادية البحتة. وبالتالي، يحق للضحية أن يحصل على التعويض بمجرد استيفاء شروط المادة 92.9 ومن جانب اخر كان موقف المشرع غير واضحاً بالنسبة للخسائر والاضرار التجارية، إلا أن مجلس الدولة الفرني في قراره الصادر في 6 نيسان لسنة 1990، قرر صراحة عدم استبعاد هذه الصورة من الأضرار، ذلك استناداً إلى أن المشرع لم يضع أي قيود أو لم يستبعد 


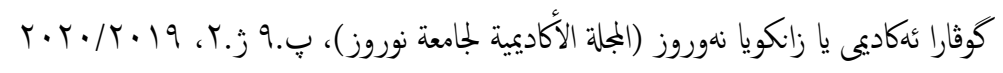

بعض المزايا لضحايا جرائم.24 كذلك بعد صدور قانون 6 تموز 1990 والذي عدل من رئيسي على الاصلاح من تغيير أو تبديل أو تعديل القوانين وغيرها من التشريعات النظام الذي شيدته القوانين السابقة، لم تعد الدولة هي التي تلتزم بأداء التعويض الذي المعمول بها.

وفي مجال إصلاح التشريعات المدنية، نلاحظ بأن هناك قفزة قانونية نوعية في نظر المشرع العراقي في مسألة التعويض عن الاضرار، حيث ينص أحد أحكامه (حاية المتضررين من لا نكفي أحكام المسؤولية غير العقدية لإصلاح الضرر اللاحق بهم،





وما يلاحظ في هذا البند أنه قد أكد على مفهوم جديد في التشريع العراقي وهو مسألة حاية الضحايا. وهذا يعتبر بحد ذاته مفهوماً جديداً، وبالتالي يشار إلى أنه في حال عدم كفاية قواعد المسؤولية التقصيرية لجبراضرر اللاحق بالضحية، فإن مبدأ اخر يأتي لإصلاح الضرر وهو مبداً التأمينات الاجتاعية، وبذلك يتفق هذا النهج مع الاتجاهات الحديثة المعتمدة في التشريعات الحديثة، بما في ذلك التشريع الفرني الذي نص على انشاء صندوق لضمان تعويض الضحايا. وهو ما يؤكد ما ذهبنا اليه وماجاء في الفقرة





وعلى ضوء فلسفة قانون إصلاح النظام القانوني، استمرت عملية الإصلاح وأسفرت تلك الجهود التشريعية المى إصدار مشروع القانون المدني لعام 1986 غير النافذ، وبموجب هذا المشروع تغير نهج التشريع العراقي الوارد في المادة (219) من القانون المدني العراقي رڤم 40 لسنة 1951 والذي أكد فيه أن مسؤولية إلادارة هي مسؤولية المتبوع عن اعمال تابعه أي المسؤولية عن اعمال الغير. 29 حيث اعتمد مبدأ معاصر لمسؤولية الدولة، وهو مسؤولية مباثرة وذاتية. حيث نصت في المادة (424) في هذا المشروع على أنه (اذا تعذر معرفة المسؤول عن الضرر الذي اصاب الغير، أو




وتعتبر هذه محاولة تشريعية تممة من وبحة نظر التشريع العراقي في مبدأ تكفل الدولة بتعويض الاضرار التي تصيب المواطنين في حالة تعذر معرفة المسؤول عن الضرر أو استحالة الحصول على التعويض منه. وهكذا أستمر الوضع في ظل النظام السابق الى حين سقوطه في سنة 2003 وبداية مرحلة جديدة في العراق وفي جميع الجوانب،ولا



تقرره لجان التعويض، وإنما أصبحت الجهة التي تقوم بتعويض ضحايا النزاعات الداخلية هي صندوق الضمان والذي تغير تسميته لتصبح صندوق ضحايا الأعال المسلحة والأعال الإرهابية والجرائم أخرى.

\section{3. المبحث الثاني: موقف المثرع العراقي من تعويض ضحايا الزاعات المسلحة غير} الدولية

سوف نتناول من خلال هذا المبحث بيان الملاح التثريعية لنعويض ضحايا النزاعات المسلحة غير الدولية في المطلب الاول، ثم تعويض ضحايا النزاعات المسلحة غير الدولية وتقدير التعويض ومصادر تمويل التعويض في المطلب الثاني و المطلب الثالث.

\section{3 المطلب الهول : الملاح التشريعية لتعويض ضحايا الززاعات المسلحة غير الدولية}

التعويض ضحايا النزاعات الداخلية في التشريع العراقي يكن تقسيمها الى مرحلتين، مرحلة ما قبل عام 2003، فني دستور المجهورية العراقية المؤقت الصادر في عام 1970 لاتوجد إنارة الى تعويض ضحايا النزاعات، ولم تصدر قوانين بهذا الصدد أيضاً، على عكس ما فعله النظام القانوني المصري عندما نص على مبدأ دستوري لإلززام الدولة بتعويض كل اعتداء يقع على المواطنين، حيث نصت المادة (57) من دستور سنة 1971: (أن الدولة تكفل تعويض المواطنين جراء الاعتداءات على حياتهم وسلامتهم). على الرغز من أن الدستور العراقي المؤقت قد اثار الى مبدأ النكلفل الاجتاعي في المادة (10) منه وضمن الباب الثاني الذي خصصه للأسس الاجتماعية

والاقتصادية للجمهورية العراقية.25

إن متتضيات التكافل الاجتماعي في الدولة باعتباره مبداً دستوري يلتي بضلاله على وجوب توفر مبدأ تكفل الدولة الاضرار الناشئة عن الكوارث والحرب (النزاعات المسلحة الداخلية) والفيضانات، ومع ذلك لم نلاحظ أي تشريع خاص بعد صدور هذا الدستور ينص على مبدأ تكفل الدولة بتعويض الاضرار الناجمة عن أعمال الجماعات

المسلحة والجرائم بصورة عامة والنزاعات المسلحة الداخلية بصورة خاصة'26. وفي مرحلة تشريعية لاحقة ومن أجل بناء القانون العراقي بموجب ايدلوجية الحزب الحلك في ذلك الوقت، صدر قانون إصلاح النظام القانوني رقّ 35 لسنة 1977. ويعتبر هذا القانون بمثابة ورقة لإصلاح النظام القانوني في العراق، حيث يعتمد بشكل 




يصاب أو يستشهد نتيجة تاك الاعمال، بل على كلمة تعويض مناسب وهي كلمة مرنة، ويككن أن تحمل أكثر من معنى بالاضافة الى ذلك، عرض شروطاً لتعويض المواطن العادي، فقد الزم ان تصدر تعليمات من قبل وزير المالية ومصدق عليها من قبل رئيس الوزراء تتضمن تحديداً لمعنى العمل الارهابي ومقدار التعويض الواجب دفعه. لذلك يتبين بأن هناك مفارقة بين حالتين، فإنه يتطلب لتعويض المواطن غير الموظف تحديد مفهوم الاعمال التخريبية ولم يتطلب ذلك بالنسبة للمواطن الموظف لدى الحكومة، وهذا يعني أن الدولة قد تشددت في الشروط بالنسبة للمواطن غير الموظف.

ووفقًا للفقرة الرابعة من هذا الامر صدرت تعليمات ذي الرقّ (3) لسنة (2005) لتعويض الشهاء والمصابين نتيجة الاعمال الارهابية حيث تم معالجة الملاحظات والنواقص الموجودة في الامر (10) الصادر في سنة (2004)، ففي الفقرة الثانية منها قد نصت على مبلغ تعويض معين يمنح لذوي المواطن سواء آكان (موظفاً أم غير

$$
\text { موظف) على حد سواء35. (- ماء. }
$$

وعلى الرغز من الملاحظات الموجودة على الامرين (10) لسنة 2004 لمجلس الوزراء ورة (3) لسنة 2005 لوزارة المالية، الا أنه بموجب هذين الامرين تم تثبيت مبدأ التعويض للضحايا بشكل قانوني ووفق آليات وضوابط قانونية على عاتق الدولة. ومن خلال ما تقدم يتيين أن هذه الأوامر صدرت بموجب قانون ادارة الدولة العراقية للمرحلة الانتقالية، وفي مرحلة هامة في العراق تم الاتفاق على دستور جمهورية العراق الدائم لسنة 2005 من قبل الجمعية الوطنية العراقية ومن ثم عرض هذا الدستور على الشعب العراقي في 2005/10/15 عن طريق الاستفناء والذي وافق عليه الشعب العراقي.36 حيث تنص المادة (132) من الدستور العراقي على مبدأ التزام الدولة بتعويض الضحايا والتي جاء فها: "أولاً: تكفل الدولة رعاية ذوي الشهداءو السجناء السياسيين والمتضررين من المارسات التعسفية للنظام الدكناتوري المباد. ثانياً : تكفل الدولة تعويض اسر الشهاء والمصابين نتيجة الهعال الارهابية. ثالثأ: ينظم ما ورد في البندين (اولاً) و(ثانياً) من هذه المادة بقانون." وصدر بعد ذلك القانون رقز (20) لسنة 2009 (قانون تعويض المتضررين جراء العمليات الحربية و الاخطاء العسكرية والعمليات الارهابية) والذي سنتطرق اليه بشيء من التفصيل لاحقاً.
ولسد الفراغ التشريعي الحاصل في تلك المرحلة، اصدر بجلس الحكم في العراق، قانون ادارة الدولة العراقية للمرحلة الانتقالية، وكان بمثابة القانون الاعلى في البلاد لإدارة شؤون العراق خلال المرحلة الانتقالية الى حين قيام حكومة منتخبة تعمل في ظل دستور شرعي دائم، وبسبب التغير الكبير الحاصل في النظام السياسي أدى ذلك الى ظهور الصراعات الدامية بكافة جوانها واشكلها على الساحة العراقية، ومن إفرازات تلك الصراعات نتجت ظاهرة الجماعات المسلحة وظاهرة الارهاب بشكل كبير وواسع التي تركت الالآف من الضحايا، ويلاحظ ان قانون ادارة الدولة للمرحلة الاتنقالية لم يشر ايضاً الى التعويض، ولكن في ملحق قانون ادارة الدولة العراقية للمرحلة الانتقالية، تم تفويض السلطة التنفيذية بإصدار القوانين والتعليمات والاوامر للتعامل مع مسائل استثنائية التي تتطلب تشريعات لتنظيها. لذلك صدر الأمر الوزاري ذي الرقٍ (10) لسنة (2004) والخاص بـ (تعويض الشهداء والمصابين نتيجة الاعمال الارهابية) وذلك استناداً لاحكام المادة السادسة والعشرون من قانون ادارة الدولة العراقية للمرحلة الانتقالية واحكام القسم الثاني من ملحقه، وكان يتضمن هذا الامر تعويضات تنح لمنتسبي الجيش والشرطة وحاية المنشآت العراقية. وكذلك المواطنون الذين استشهدوا أو يصابون بعاهة مستديمة نتيجة النزاعات المسلحة والاعمال الارهابية وهم على ابواب مراكز التطوع بقصد التطوع الى جماز الشرطة والجيش


وتنص الفقرة الرابعة من هذا الأمر على منح تعويض مناسب للمواطنين الذين يستشهدون أويصابون بعاهة مستديمة نتيجة الاعمال الارهابية و النزاعات المسلحة غير الدولية، الذين لم يكونوا من ضمن منتسبي الجيش والشرطة، شريطة أن يحدد مفهوم العمل الإرهابي ومقدار التعويض وفقاً للتعليات التي يصدرها وزير المالية وبعد موافقة رئيس الوزراءعليها33. ومما تقدم يلاحظ على هذا الامر انه يعد خطوة عمة في مسألة تعويض ضحايا الجماعات المسلحة. حيث جاء في مرحلة للتعامل مع العواقب التى خلفتها ظاهرة النزاعات المسلحة الداخلية. وذكر البعض من الفقهاء بعض الملاحظات على الأمر منها، ان الامر قد ميَزبين المواطن العادي (غير الموظف) والمواطن الموظف لدى الحكومة، بحيث حدد مقدار التعويض الواجب على المكومة دفعه إلى الشهاء والمصابين بمقدار معين ولكنه لم يحدد مبلغ النعويض المدفوع الى الشخص العادي (غير الموظف) الذي 




من المقيمين على أراضيها من خطر التعرض لحالات طارئة أو لنزاعات مسحلة وحوادث ارهابية 40. وبالنظر إلى أحكام القانون رق (20) لسنة 2009 المعدل، نجده وضع اطاراً عاماً يحدد بموجبه عناصر التعويض لضحايا العمليات العسكرية والنزاعات المسلحة، ويعالج الموضوع من الجوانب الاتية وهي: (نوع الضرر والمستفيدون من التعويض والجهة المسؤولة عن تنظيم إجراءات التعويضات ومقدار التعويض). وسنبحث في الضرر في الفرع الاول والجهة المسؤولة عن اجراءات التعويض في الفرع الثاني

\section{(1.2.3. الفرع الاول: من حيث نوع الضرر}

حدد القانون المذكور نوع الأضرار التي يتم التعويض عنها، إذ نصت المادة (2) منه على أن يشمل التعويض الأضرار المتثناة في أولاً: " الاستشهاد او الفقدان او الاختطاف او الاصابة جراء العمليات المنصوص علها في هذا القانون، ثانياً: العجز الكلي أو الجزئي بناءً على تقرير لجنة طبية مختصة، ثالثاً: الإصابات والحالات الأخرى التي تتطلب علاجاً مؤقتاً بناء على تقرير اللجنة الطبية الختصة في هذا المجال، رابعاً : الأضرار التي تصيب الممتلكات، خامساً: الأضرار المتعلقة بالوظيفة والدراسة4". من خلال ما تقدم يظهر لنا أن هذا القانون يشمل خمس فئات من الضرر، ثلاثة منها تصيب الانسان واثنتان تتعلق بالملكية والدراسة والوظيفة. إن الفئات التي تصيب الإنسان حاول المشرع توضيحها بدقة، فييها بالاستشهاد أو الفقدان أو الاختطاف أو الإصابة، فهي واضحة بالنسبة للاستشهاد والفقدان أي انقطاع الاخبار عن الشخص أو عن مكانه و عمله، ثخ الاختطاف وهو نقل شخص من مكان الى آخر جبراً، ومن ثخ الإصابة فتشمل جميع أنواع الإصابات التي من الممكن ان يتعرض لها الأنسان، جفاءت الفقرة ثانياً التي بينت ننائُ الإصابة بأن تسببت بعجز كلي أو جزئي، والفقرة ثالثاً: بينت حالات الإصابة التي تستلزم فترة شفاء مؤقتة بموجب تقرير طبي من لجنة

متخصصة.

أما بالنسبة للنعويض عن الضرر المتفامُ20 فلم يأخذ به المشرع في هذا القانون، وبمعنى ذلك إذا كان هناك مصاباً من النزاعات المسلحة بأضرار جسدية جسمة تتطلب علاجاً دائماً فإنه لا يستطع المطالبة بالتعويض في هذه الحالة عن الاضرار التي يكن أن تتفاقٍ مستقبلاً، ويعتبر هذا نقصاً في هذا القانون ينبغي تلافيه، وعلى عكس ذلك المشرع الفرسي فقد أخذ بها النوع من التعويض في قانون صندوق الضمان رقم 9 أيلول لسنة
أما بالنسبة لأقليم كوردستان العراق، فإنه عانى من ظاهرة النزاعات المسلحة الداخلية ومنذ سنوات طويلة. وبعد الانتفاضة في اقليم كوردستان عام 1991 وانتخاب أول سلطة تثريعية (برلمان كوردستان) وتأسيس حكومة اقليم كوردستان، و طوال تلك كُ كر السنوات وحتى عام 2004، وعلى الرغز من وجود ضحايا فإن السلطة التشريعية في الاقليم لم تصدر أي تشريع خاص بشأن التزام الدولة بتعويض ضحايا النزاعات المسلحة الداخلية، وفي ظل هذا الفراغ التشريعي ومع تزايد هذه الاعمال اخذت حكومة اقليم كوردستان العراق هذه المسألة على عاتقها، وذلك بإصدار أمر وزاري صادر من رئاسة مجلس الوزراء لاقليم كردستان ذي الرق (6262) بتاريخ 2004/10/17، حيث بموجب هذا الامر الوزاري تم توجيه التعليات لوزارة المالية والاقتصاد في حكومة الاقليم بتأمين رواتب لأسر الشهاء والمصابين من جراء النزاعات والاعمال الرهابية، حيث يتضمن هذا الامر الوزاري تقديراً لمقدار التعويضات للمواطنين ( الموظف وغير الموظف ) الذين استشهدوا أوأصابوا من جراء تلك الععال37. ومن أجل معالجة النصص التشريعي الذي ولده عدم وجود تشريع خاص بكلفة الارهاب والجماعات المسلحة وتعويض الضحايا، أصدرت السلطة التشريعية قانون خاص بكافة الارهاب رقز (3) لسنة (2006)، والذي تم المصادقة عليه من قبل رئيس اقليم كوردستان في 2006/4/1038، وقد تضمن هذا التشريع مبدأ هاماً، حيث نص في المادة (15) على أن "تتكفل حكومة اقليم كوردستان العراق، برعاية ضحايا الافعال الارهابية وتعويض المتضررين منها). لذلك سنبين من خلال المطلب الثاني تعويض ضحايا النزاعات الداخلية وفقاً لقانون رق (20) لسنة 2009 المعدل.

2.3. المطلب الثاني: تعويض ضحايا النزاعات المسلحة غير الدولية وفقًا لقانون رةز (20) لسنة 2009 المعدل متى أعلنت الدولة بمتضى قانون خاص 39، مسؤوليتها عن تعويضِ ضحايا العمليات العسكرية والنزاعات المسلحة الماخلية والاعمال الارهابية، فانها لا تستطع دفع مطالبات مرفوعة اليها بالتعويض بعدم كفاية أدلة الاثبات أو بأعال السيادة اللازمة لأقامة المسؤولية ضدها بمتضى الخطأ الواجب الاثبات، لأن المسؤولية الناشئة عن مطالبة الدولة بالتعويض في هذه الحالة، تنشأ بناءً على عنصرِ الضرر لا على أساس عنصر الخطأ، كما لايجوز للدولة أيضا التمسك بأعمال السيادة وعدم تعويض ضحايا النزاعات المسلحة، في حالة عدم صدور قانون خاص للمطالبة بالتعويض، ورد دعوى ترى المدعي وعدم الحكى له بالتعويض. وبالتالي تكون الدولة ملزمة بحاية المواطنين وغير هم 




والعمليات الارهابية) وترتبط بدائرة شهاء ضحايا العمليات الحربية والاخطاء العسكرية والعمليات الارهابية في مؤسسة الشهاء، وللجنة الفرعية فتح مكاتب لها




أن هذا القانون قد نص على تشكيل ثلاثة أصناف من اللجان لإدارة عمل واجراءات توزيع التعويضات حسب نوع الضرر، وهذه اللجان هي لجنة مركزية مقرها في بغداد وترتبط بالأمانة العامة لملس الوزراء48،والتي تنسق مع دائرة شهداء ضحايا ومؤسسة الشهاء، ولجان فرعية في بغداد ولجنة في اقليم كوردستان ولجنة في كل محافظة غيرمنتظمة في إقليم ترتبط بدائرة شهداء الضحايا في مؤسسة الشهداء لتعويض المتضررين، ولجنة في كل وزارة أو جهة غير مرتبطة بوزارة، وأن مهام هذه اللجان تختلف ما إذا كانت اللجنة فرعية أو مركزية، وبإختصار إن عمل هذه اللجان ينصب على استلام الطلبات وتقدير قيمة التعويض ورفعها الى وزارة المالية لصرف تلك

التعويضات.

على الرغز من صدور القانون رقّ (20) لسنة 2009 المعدل، إلا أن عملية تنفيذه لم يخلومن قصور وتحديات. حيث يشكل هذا القانون إلى حد ما دلالة رمزية على الصعوبات التي تواجه تنفيذ برنامج تعويض الضحايا في خضم النزاع الجاري وضعف مؤسسات الدولة. فضلاً على ذلك الإرتباط بمؤشرات وهياكل مؤسساتية ينشئها



لقد أدت حالات التأخير الواسعة النطاق إلى إفساد عملية تقديم تعويض للضحايا بموجب، فإنه على الرغز من صدور القانون في أواخر عام 2009، إلا أنه لم تصدر وزارة المالية التعليمات اللازمة لوضع القانون حِّز التنفيذ حتى منتصف عام 2011، وحتى بعد بدء التنفيذ، وحسب بعض التقارير قد استغرق معدل عامين لمعالجة مطالبة واحدة.49. ولهذا السبب ادت المى تراكم عدد كير من المطالبات في عدد كيرمن المحافظات بسبب ارتفاع عدد الضحايا الذين يطالبون بالتعويض. حيث أن الإجراءات المعقدة في القانون المذكورتعتبر السبب الرئيسي للتأخير في تقديم تسهيلات للضحايا وتعويضهم بطريقة مناسبة. وبالإضافة إلى ذلك، لم يَّم هذا القانون بإختيار مؤسسة مركزية قوية مسؤولة عن تقديم تعويض للجبر الاضرار. حيث أن اللجنة المركزية واللجان الفرعية المعينة بموجب القانون رقخ (20) لسنة 2009 المعدل يتكونون من مثثلين فقط عن وزارات حكومية مختلفة يرأسها قاضٍ. وهذا يعني أنه لا توجد مؤسسة
أما بالنسبة الى الصنف الرابع والخامس من الأضرار فتعلقت بالممتلكات والدراسة والوظيفة، فهي غيرموجودة في القوانين المقارنة التي تناولت حالات التعويض عن


جزئية وأمر في غاية الأهمة، وكذلك من يثبت تضرر دراسته أو وظيفته 45. من خلال ما تقدم، يتيبن لنا، إن إطار عمل القانون رقٌ (20) لسنة 2009 المعدل بشكه الحالي من غير المربح أن يكون قادراً على أن يعالج وعلى نحو فعال ك الإنتهاكت التي تم إرتكابها خلال النزاع المسلح الأخير. وفي حين أن التزكيز المنصوص عليه في القانون هو على المتضررين جراء العمليات الحربية والأخطاء العسكرية والعمليات الإرهابية، فإنه لم يحدد من ناحية أخرى أنواع الإنتهاكات الموجودة ضمن هذه الفئات. على مستوى التطبيق، فإن الأشخاص المشمولين بالقانون ه فقط هؤلاء الذين قتلوا أو أختطفوا أو فقدوا، المصابين بجروح جسدية، الأشخاص الذين أُجبروا على ترك الدراسة أو الوظيفة، وأوليك الذين فقدوا متلكاتهم.

على الرغز من أن تحديد أولوية معينة من الاتتهاكات كان له ما يبره في المكثير من الحالات التي يكون فهيا توفير تعويض الأضرار لجميع الضحايا أمراً غيرجدياً، حيث استبعد هذا القانون وبوضوح الانواع الرئيسة من الانتهاكات التي كانت سات رئيسية للنزاع. فعلى سبيل المثال، إن ضحايا العنف الجنسي، والاشخاص الذين يعانون من الصدمات النفسية، والاطفال المجندين في الخدمة العسكرية القسرية لا يكق لمم اللجوء إلى سبل الإنتصاف بموجب هذا القانون كما يَتتقر القانون إلى المنهج الجماعي في تعويض الأضرار للضحايا الذين تم إستهدافهم بسبب إنتاءاتهم كما حصل مع الكثير من الأقليات الإثنية والدينية في العراق.

\subsection{3. الفرع الثاني: الجهة المسؤولة عن إجراءات الثعويض}

في إطار اجراءات تعويض الضحايا من المسؤولية المدنية للدولة عن النزاعات المسلحة خول المشرع لجان خاصة لتتولى عن إجراءات التعويض46، إذ بينت المادة (3) من القانون مائتي " أولاً: لجنة مركزية تسىى (اللجنة المركزية لتعويض المتضررين جراء العمليات الحربية والاخطاء العسكرية والعمليات العسكرية) ويكون مقرها في بغداد وترتبط بالامانة العامة لمجلس الوزراء بالتنسيق مع دائزة شهاء ضحايا العمليات الحربية والاخطاء العسكرية والعمليات الوهابية في مؤسسة الشهاء، ثانيا: لجان فرعية في بغداد ولجنة في اقليم كوردستان ولجنة في كل محافظة غير منتظمة في اقليم تسمى (اللجنة الفرعية لنعويض المتضررين جراء العمليات الحربية والاخطاء العسكرية 




50 من قيمة الضرر في تاريخ حدوثه حسب وصفه ونسبة ضرره مستندة في ذلك المى المادة (4/ز) من أسس المطالبة بالتعويضات وكيفيتها عدد (1) لسنة 2010 المعدلة التي أصدرتا وزارة المالية استناداً المى المادة (15) من قانون تعويض المتضررين، ويختلف هذا التعويض من حاله إلى أخرى وفقًا لقيمة تقدير التعويض 53. وتقوم هذه اللجان بتقديرالتعويض من خلال نص المادة (15). أما بالنسبة لكيفية تقدير التعويض بشأن الاضرار الناجمة عن النزاعات المسلحة الداخلية، وكما لوحظ، فبعد امتناع القضاء العراقي عن النظر في طلبات التعويض لضحايا النزاعات المسلحة وجرائم الارهاب، حيث صدر قرار محكمة التمييز الاتحادية54،والني كلف بعمل استلام الطلبات من قبل لجان مرتبطة بالسلطة

$$
\text { التنفيذية وعملها أقرب لعمل الادارة منه الى القضاء.5 }
$$

كما أقر المشرع العراقي الإجراءات القانونية بالطعن في قرارات لجان النعويض سواء اللجان الوزارية أو الفرعية، حيث جاء في المادة (7- أولاً): "للمتضرر أو ذويه او وزارة المالية الاعتراض على قرارات وتوصيات اللجان الفرعية واللجان المشكلة من الوزارات والجهات غير المرتبطة بوزارة لدى اللجنة المركزية خلال(30) ثلاثون يوم من


في قراراتها لدى محكة القضاء الاداري بعد (30) ثلاثين يوما من تاريخ التبليغ بنتيجة القرار ويكون قرار المككة قابلا للطعن لدى المحكة الادارية العليا خلال (30) ثلاثين يوما من تاريخ التبليغ بقرار الحكى الصادر من المحكمة او اعتباره مبلغا به"56.5 تصني. وفي هذا الصدد، نجد أن القضاء57 عند تقديره للتعويض عن الضرر الذي لحق بالمتضرر لايكنه تقديره جزافاً، بل لكل حالة على حدة، وبالتالي نهيب بالمشرع العراقي من خلال قانون رقٌ 20 لسنة 2009 المعدل السير على هذا النهج والذي استناداً له صدرت احكام جزافية 58، حيث تم دفع مبلغ قدره ثلاثة ملايين وسبعمائه وخمسون الف دينار كتعويض لعائلة الشهيد .59 وفي قضية أخرى، دفت اللجنة أيضاً مبلغ جزافي اخر للجريح والمعوق، حيث منحه مبلغ مليونان وخمسائة الف دينار 60. وتدفع هذه المبالغ حسب معيار موضوعي ومبلغ ثابت جزافاً، ودون مراعاة لشخص الضحية


يختلف من شخص إلى آخر في كونه طفل قاصر أو بالخ لديه عائله أذ لابد من الأخذ بتلك الظروف عند تقدير التعويض ولكل حالة على انفرادم6.
متفرغة لهذا العمل، حتى لو تم وضع بعض التسهيلات. الواقع أنه في القانون، لم يطلب من اللجنة المركزية أن تجتمع سوى مرة واحدة في الاسبوع، واللجان الفرعية مرتين والذي كان ومن دون شك سبباً رئيسياً لتزايد في تراك الدعاوى 50. بالإضافة إلى ذلك لايوجد أيضاً منظومة تمويل مركزية لتشغيل المدفوعات. وغيرها من أنواع التعويض بموجب القانون رقّ (20) لسنة 2009 المعدل وبدلاً من ذلك، تُقدم اللجنة المركزية واللجان الفرعية قراراتها إلى وزارة المالية وهيئة التقاعد والسلطات المحلية المسؤولة عن إصدار منح التعويض، ومدفوعات التقاعد، وقطع الأراضي على التوالي. وهذا يعني أنه حتى في حالة تلقى الضحايا قراراً إيجابياً بشأن التعويض عن الضرر الذي لحق بهم ، فإن بمموعة من العوامل يمكن أن تحول دون تسليم التعويض

$$
\text { إلهيه عن الأضرار من قبل المكاتب الحكومية الأخرى }
$$

هناك تغيير مؤسسي همم آخر مثر للجدل، أدخله قانون رق (20) لسة 2009 المعدل، وهو أن المسؤولية عن تعويض الأضرار النزاعات الاخيرة قد تم نقلها إلى سلى مؤسسة الشهاءء5. ولقد أثار هذا التغيير التوترات السياسية. حيث إن مؤسسة الشهاء ترتبط إرتباطا وثيقاً (بزب الدعوة)، الذي يعطي أولوية عالية لتعويض ضحايا نظام صدام حسين. ونتيجة لذلك، فإن الكثيرين داخل المؤسسة يقاومون فكرة إدماج ضحايا العمليات الحربية والعمليات الإرهابية تحت مسمياتهم ومنحهم نفس الامتيازات التي تمنح لضحايا النظام السابق. وبسبب هذه التوترات السياسية، حيث أدت الى عدم تنفيذ هذا القانون في أقليم ؤردستان وعدم تشكيل أي لجان فرعية في الاقليم لحد الان، مما ادى الى حرمان ضحايا النزاعات المسلحة الداخلية من التعويض عن الاضرار. وبالإضافة إلى ذلك، بسبب هذه الصراعات السياسية أدت ذلك الى عدم تفعيل اللجان الفرعية في محفظات كركك، وينيوى، والأنبار وصلاح الدين مما سبب وقق عملهم بالكامل لمدة ثلاثة أشهر، والبعض الأخر لأكثر من عامين.

3.3. المطلب الثالث: تقدير التعويض وفقاً للقانون رق 20 لسنة 2009 المعدل ومصادر تمويل التعويض سنحاول من خلال هذا المطلب بيان تقدير التعويض وفقًا القانون رقّ 20 لسنة 2009 المعدل في الفرع الاول ومصادر تمويل التعويض في الفرع الثاني.

\subsection{3 الفرع الاول: تثدير التعويض وفقاً القانون رة 20 لسنة 2009 المعدل}

فيا يتعلق بمسالة تقدير التعويض لضحايا النزاعات المسلحة، حيث تم تفويض اللجان للنظر في طلبات النعويض للمتضررين، ويتم دفع قيمة الأضرار المادية بما لايزيد عن 




إن تطبيق قاعدة ما لحق المتضرر من خسارة وما فاته من كسب كأساس لتعويض المتضررين وما جرى عليه تطبيق المحاك يمنح عن قصور في كفالة حق المتضرر في التعويض عن الأضرار التي تصيبه وذلك لجسامة هذه الأضرار وتغيرها مقارنة بحالة الضعف التي سوف يعانها الضحية من جراء العمليات المسلحة الناجمة عن اخطاء موظفي الدولة في اطار مسؤوليته في حفظ الأمن والوقاية من تلك الاعمال67. وإن امتناع القضاء عن النظر بطلبات تعويض ضحايا النزاعات المسحلة وتنفيذ قواعد المسؤولية المدنية، أثر على المتضررين منه، والمفروض أن يكون القضاء هو الضمان للضحايا في حصولم على تعويض كامل من جراء تلك الاعمال 68. وبناء على ذلك، نأمل أن يتدخل المشرع في تعديل الأحكام المتعلقة بالتعويض ووقت تقديره من أجل تحقيق الانساق بين مبلغ التعويض والضرر المتغير للمتضررين من جراء النزاعات المسلحة وتعديل قانون رقّ 20 لسنة 2009 المعدل، حيث لابد أن يأخذ بنظر الاعتبار عند تقدير التعويض قيمة النقود وارتفاع الأسعاربشكل مستمر حتى ينسجم مقدارالتعويض مع ججم الضرر، سواء كان ذلك من خلال عمل اللجان المشكلة بموجب هذا القانون في تقدير التعويض مباشرة استنادا إلى نسبة العجز التي يعاني منها المتضرر. وكذلك يمكن الاستعانة بأهل الخبرة من الأطباء والخبراء لتقييم قيمة التعويض المناسب لكل حالة بمردها، وعدم التزام لجان التعويضات بمبالغ محدده تدفح لكل شخص مصاب، بغض النظرعن ظروفه الشخصية والاجتاعية.69. وتجدر الاثاره إلى أن الهدف من التعويض هو أعادة التوازن نتيجة للضرر الحادث بغعل الخطأ، وهذا لايتحقق إلا بإعادة المتضرر الى الوضع الذي يكون فيه لو لم يقع الفعل الضار، وإذا كان القاضي يتمع بالحرية في تقدير التعويض إلا أن هذا التقدير يجب أن يكون متناسباً مع الضرز الواقع. ولكي بتمكن القاضي من إجراء تثييم حقيقي لتعويض الأضرار الناتجة عن أخطاء العمليات العسكرية في مجال الحفاظ على الامن، يجب أن يكون القاضي على دراية ببعض الثفاصيل الامنية. وهذا لايمعه من الاستعانة بالخبير في هذه الامور الخاصة، فيكون قراره أكثر عدالة للمتضرر والمسؤول عن الضرر(الدولة)، وهذا ما أكدته المادة قانون الإثبات العراقي رقّ 107 لسنة 1979 المعدل وجاء فهيا "تتناول الخبرة الأمور العلمية والفنية وغيرها من الأمور اللازمة للفصل في الدعوى دون المسائل القانونية"70. ومع ذلك، فإن الحبير ليس هو الذي يحدد مبلغ التعويض بشكل قاطع، لإن القاضي له الحق في مناقشة الخبير في هذا الصدد، كما أنه قد يغير فيا قدره الحنبير المى الزيادة أو
من ناحية أخرى، لم يتناول المشرع العراقي في القانون رقٌ 20 لسنة 2009 المعدل النعويض عن الضررالمعنوي، بخلاف المثرع المصري، الذي استند على القواعد العامة للمسؤوليه، حيث التعويض عن الضررالأدبي أسوة بالضررالمادي، وهذا ما أكده من خلال نص الملادة (222) من قانونه المدني، واتبع المشرع الكويتي النهج نقه، حيث التعويض عن الضررالأدبي أيضا وفقا لقواعد المسؤولية المدنية هو التعويض الكمل. وأما موقف المشرع المصري ازاء تقدير النعويض فقد تناولها في المادة (171/أ).6. وبالاضافة الى ذلك نص القانون المدني المصري في المواد(221) و(222) على مسالة تقدير التعويض من قبل القاضي عن الضرر الحاصل وهي تعد في القانون المصري من مسائل الواقع التي يستقل بها قاضي الموضوع دون خضوع لرقابة محكة النقض ويشمل التقدير الأضرار المادية والأدبية. اما موقف القضاءومن خلال محكة النض المصرية التي استقرت على ان تقدير التعويض عن الضرر يجب ان يكون وقت الحكى وليس



ومع ذلك، عند تقدير التعويض عن الاضرار عن النزاعات المسلحة والاعمال الارهابية، يجب أن نميز بين الحق محل الاعتداء والتعويض عن الضرر الواقع على هذا الحت. ولأجل تقدير التعويض عن تلك الاضرار، يجب أن يكون هذا التعويض متناسباً حسب مبدأ الجبرالكامل للضرر. بالإضافة الى ذلك يجب مراعاة الظروف الشخصية للضحايا، على سبيل المثال، مهنة الضحية، التي لها تأثير كبير على الأضرار


أما المشرع الفرسي فقد أورد قانون خاص65 - سبقت الاشارة له - بحقوق ضحايا النزاعات المسلحة والأعمال الإرهابية، وأنشأ صندوقاً لهذا الغرض وحرص على أن لايفقد حق الضحية في التعويض. وتكون الحكومة الفرنسية مسؤولة من خلال صندوق خاص بدفع التعويضات الاجتاعية بغض النظر عمن تسبب في الإصابة. وفي مجال تقدير النعويض عن الاعمال التخريبية منح المثرع لجنة النعويض صلاحية لتحديد القواعد وتقييها، وبعد صدور قانون 6 تموز1990، أصبح التعويض عن الضرر الجسدي كاملآ، حيث لجأ المشرع الفرنسي الى لجان لجبر الضرر عندما أنشأ صندوق ضمان خاص للضحايا. وكذلك تولت هذه اللجان تقدير التعويض عن الضرر الادبي النابم من تلك الاعمال من خلال القانون المذكور اعلاه، ويحق للشخص المتضرر طلب النعويض عن تفام الضرر، حيث يقدر ذلك من خلال وجود أدلة إثبات على أن الضرر قد تفاق ويرفع الطلب الى الصندوق 




مقدار التعويض يرتفع، ويتم تقدير التعويض وفقاً لمعيار شخصي حسب الظروف الشخصية للضحية. ولكن هذا الوضع بعيد عن قانون 20 لسنة 2009 المعدل حيث يتم دفع تعويضات للمتضررين من العمليات الارهابية بمبالغ مقطوعة جزافية لكل متضرر دون الاعتداد بالظروف الشخصية لكل متضرر.

\subsection{3. الفرع الثاني: مصادر تمويل الثعويض}

في الواقع لم يتضمن هذا القانون نصاً يشير الى موارد تمويل التعويض لضحايا النزاعات المسلحة على الرغز من أن إنشاء صندوق للتعويض يعد من الامور الاساسية في مجال التعويض، ولاسيا بعد تأكيد إعلان الام المتحدة بشأن المبادئ الاساسية لتضمين العدالة لضحايا النزاعات على ضرورة انشاء صندوق للتعويض، بقولها (ينبغي

تشجيع إنشاء وتعزيز وتوسيع الصناديق الوطنية المخصصة لتعويض الضحايا)7.7. إلا أن المشرع العراقي ترك هذه المسألة الى الموازنة العامة للدولة ويعتبر هذا عبء

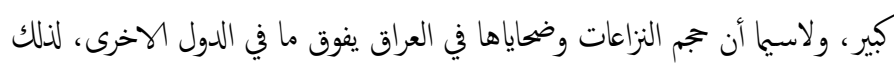
نجد كل من ألمانيا وفرنسا وأمريكا وكولومبيا قد خصصت بنداً من الميزانية لتمويل التعويض ويزداد سنويأ76، وأن أهم مصدر لتمويل هذا الصندوق تكون من شركات التأمين على الاموال، أي التى تحترف تأمين الخسائر المالية، إذ تلتزم تلك الشركات



ويعتمد جزء من نجاح قانون رق (20) لسنة 2015 المعدل على تخصيص الموارد المالية لجعلها قابلة للتطبيق. وفي حين يمكن إستخدام آليات مختلفة لتحقيق هذه الغاية، إلا أن إنشاء صناديق خاصة لجبر الضرر هو ممارسة شائعة.

لذلك ندعو من المثرع العراقي إلى ضرورة إنشاء صندوق للتعويض، كما فعل المشرع المصري بإصدار قانون رقٌ 16 لسنة 2018 الخاص بإنشاء صندوق تكريم شهاء وضحايا ومفقودى ومصابى العمليات الحربية والإرهابية والأمنية وأسرهم 78، وفي السياق رك رك نسه قام المشرع الكولومبي بإصدار صندوق خاص لتعويض ضحايا النزاعات المسلحة الداخلية بموجب قانون العدالة والسلام لسنة 2005.79. وندعو من المشرع تحديد مصادر تمويله وجعل تلك المصادر تعتمد على استقطاع نسبة معينة من موارد بعض الوزارات المنتجة كوزارة الصناعة والنفط والكهرباء، وكذلك من تبرعات الجمعيات الخيرية والتبرعات الدولية والشركات التجارية. وكذلك من رجوع الدولة على متسبب الضرر في حال التمكن من معرفته، وبتحديد المصادر الثابتة لتمويل التعويض يككن للدولة الوفاء بالتعويض بطريقة لاترهق ميزانيتها لعدم تفعيل نظام التأمين في العراق،
النقص إلى الحد الذي يعتبره عادلاً لكلا الطرفين القضاة عند تقدير التعويض اللازم عن الأضرار النامة من أخطاء موظفي الدولة في مجال الأمن والتسبب في وقوع تلك الاعحال، وهذه الصعوبات مرجعها أصل الأضرار التي قد تبدأ ثم تستغرق اكتمالها زمناً، كما في حالة حصول الإصابات والتي لاتكتسب الشفاء حيث تبقى لفترة طوياة دون حسم شفاءها ما يضع القاضي في حيرة من أمره72. وقد تصدر المحكمة حكمها بالتعويض بطريقة تفصيلية محددة فيه مطالبة المتضرر التي تم الاستجابة لها وتلك التي تم استبعادها، وتعتبر هذه الطريقة أكثر توافقاً مع العدالة إذ يكون التعويض مساوياً للضرر بشكل دقيق، لأن المحكة تبتعد عن التقدير الكلي الذي يجعل المتضرر في بجالة من أمره، بل يؤدي هذا التحديد التضصيلي من جانب التضاء التطرفي كل عنصر من عناصر التعويض، وبهذه الطريقة تبين المحكة ما أذا كانت قد قبلت التعويض عن الضرر المادي والمعنوي، أو ما إذا كانت قد قبلت الأولى دون الثانية أو العكس، حتى يكون الضحية على علم بالأمر، والذي يعرف من خلالها ما إذا كانت المحكة قد عوضته عن جميع الأضرار التي أصابته أو أحتفظت بحقه في التعويض عن الأضرار المادية دون الادبية، أو تجاهل هذين النوعين وقبلت تعويض الضرر النوعي(الخاص) علاوة على ذلك، لايمكن للقاضي التعويض إلاعن الضرر الحقق ، فالأضرار الجسدية سوف لاتظهر إلا اذا تطورت الاصابة وهذا ليس مقققا. كذلك لا أحد يستطع أن ينكر أن هناك أضراراً معنوية تلحق المتضرر، وهي تتمثل بما يعانيه الضحية من حالات القلق والاكتئاب النفسي يترتب عليها أثار ضارة على حياته الخاصة، وما ينتج عن ذلك من عدم القدرة على إتمام أي عمل أو نشاط، فكل ذلك يعد بلا شك ضرراً ويجب التعويض عنه وعندما تصل الإصابة الى مرحلتها النهائية، تكون الإصابة قد تطورت بشكل كامل وصلت الى حاله من الثبات، وتعاني الضحية من اضطرابات جسدية ونفسية وآلام جسمانية، ومصاريف علاج ونققات الإقامة في المستشفى، وتكاليف الفحوص الطبية الباهظة، فضلاً عن الخللل الذي يصيب حياته العائلية والاجتاعية، وكلها تشكل أضراراً ويجب تعويضها. فضلاً عن درجة الإصابة التي تؤثر في قرار المككة بالتعويض وتحديد مقداره، وهناك عوامل أخرى تؤثر في تقدير التعويض، ومن هذه العوامل درجة الخطأ، فني مجال أخطاء رجال الامن يلاحظ أنه كلما زادت جسامة الخطأ الذي ارتكبه الشخص المسؤول عن الضرر، كلما زاد حجم الأضرار، ومن ثم 




بقرار الاخيرة لدى محكمة القضاء الاداري التي يكون قرارها قابلاً للطعن لدى المحكمة الادارية العليا.

إن قانون رقز (9) لسـنة 2009 المعـدل خالف القواعد العامة في التعويض مـن النـاحيتين، أ. اعطى تقدير النعويض إلى لجنة مركزية تسىى (اللجنة المركزية لتعويض المتضر-رين جـراء العمليـات الحربيـة والاخطلاء العسكرية والعمليـات الارهابية) ب. لم يراعي هذا القانون عناصر التعويض وأنما حدده بنسب ومبالغ مقطوعة، إذ حدد هذا القانون مبلغ التعويض بما لا يزيد عن (50\%) مـن قيمة الضرر مـن وقت حدوثه بموجب تعليمات تخالف القانون، فضلاً عن أن ذلك بك يتعارض مع مبداً جبر الضرر بالتعويض الكلمل.



نقتح على المشرع العراقي تعديل المادة (1/أولاً) من قانون تعويض المتضررين جراء العمليات الحربية والاخطاء العسكرية والعمليات الارهابية رقٍ (20) لسنة 2009 المعدل بالشكل الاتي: (بهدف هذا القانون الى تعويض كل شخص طبيعي أو معنوي عراقي وجد في العراق أو خارجه ولم يحصل على التعويض، أو أجنبي وجد في العراق بشرط المعاملة بالمثل عما أصابه من ضرر من جراء النزاعات المسحلة والعمليات الارهابية).

نقتزح الغاء الفقرة (أولاً) من المادة (3) من التعليمات المالية رقٍ (4) لسنة 2011 (التعليمات المتعلقة بالحقوق التعاقدية والمنحة لذوي الشهاء والمصابين والمفقودين والمختطفين جراء العمليات الحربية والارهابية) لتعارضها مع أحكام المادة (6) سادساً) من قانون رقز (57) لسنة 2015 النعديل الاول لقانون تعويض المتضررين رقٌ 20 لسنة 2009 التي لم تنص على ارسال قرار اللجنة الوزارية المى اللجنة الفرعية لإصدار قرار التعويض.

ونرى من الضروري تشكيل هيئة تختص بنظر طلبات التعويض لتحقيق العدالة في التعويض، ومن الأفضل ان تكون محكمة متخصصة في هذا المجال، لذا نطلب من المشرع تعديل المادتين (6،4) من القانون رقز (9) لسنة 2009 المعدل، ونتتزح أن يكون النص بالشكل الاتي: (أولاً: تشكل في مركز كل محافظة محكة للنظر في دعاوى التعويضات جراء العمليات العسكرية والرهابية والاخطاء العسكرية. ثانياً: تتكون المحكمة من ثلاثة قضاة يعينه مجلس القضاء الاعلى. ثالثاً:
وفي هذه الحالة يستطيع الضحية أو ورثثه الحصول على التعويض بطريقة سهلة وسريعة.

4. الخاثمة

بعد انتيينا من كتابة بكثنا، لابد من بيان أهم النتابُج والتوصيات التي توصلنا إلها، وهي كالآتي:

1.4

بسبب العمليات المسلحة المروعة التي تعرضت لها فرنسا في عام 1986، ونظراً لعجز القواعد العامة في المسؤولية المدنية، ولقصور نصوص التشريعات الخاصة بجرائم العنف وجرائم التجمهر والتجمع، أصدر المشرع الفرني- القانون رقٌ 861020 في 9 أيلول لسنة 1986 المتعلق بمكافة الارهاب والمساس بأمن الدولة، حيث نص المشرع وفقاً هذا القانون على مبدأ التعويض الفوري والشامل للأضرار الجسدية أياً كانت طبيعة هذه الاضرار، سواءكانت جسيمة أم غير جسيمة، من خلال صندوق الضمان مع إلزام شركات التأمين بتغطية الأضرار المالية الناتجة عن

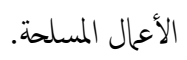

أن أساس التزام الدولة بتعويض ضهايا النزاعات المسلحة غير الدولية هو التزام دستوري، حيث تبنى الدستور العراقي لسنة 2005 مبـدأ إلزام الدولة بتعويض ضحايا العمليات العسكرية والارهابية، كما صدر اكثر من قانون في هذا الخصوص ومنها قانون تعويض المتضررين جراء العمليـات الحربية و الاخطاء العسكرية والعمليات الارهابية رقز 20 لسنة 2009 المعدل. يعد التعويض حق للضحية، وليس منحة من الدولة، إذ أن من أخص واجبات الدولة كفالة وحاية مواطنيها والمقيمين على أراضيها، فتتقرر مسؤولية الدولة بتعويضه بغض النظر عن حاجته أو مستوى دخله الاجتاعي، ودون الحاجة إلى إثبات تقصير الدولة في منع وقوع الضرر. أن التعويض وفقاً للقانون رقٌ (20) 2009 المعدل يشمل ضحايا العمليات الحربية والاخطاء العسكرية والعمليـات الرهابية، حيـث يشمل النعويض عن جميع الاضرار الجسدية والمادية والمعنوية لكل شخص عراقي طبيعي ومعنوي. من حق الضحية الاعتراض على قرار اللجنة الفرعية للتعويض في المحافظات، واللجنة الوزارية للتعويض في الوزارات لدى اللجنة المركزية للتعويضات، والطعن 




محمد عبد الواحد الجميلي ، ضحايا الإرهاب بين الأنظمة المسؤولية وأنظمة التعويضية ، دار النيضة العربية، القاهرة، 2002.




الول،1ط1، المركز القوي للاصدارات القانونة، القاهرة،2013.





\section{5 الرسائل العلمية وبجوث المنشورة}

1. احمد عبد اللطيف، المماية الجنائية لحتوق ضحايا الجرية، أطروحة دكتوراه، كلية الحقوق،






الوول 2016.
















المجلد 37- العدد13 ، 2015.








المنصورة، مصر، 2006. ممدوح أمحد سعيد، المسؤولية المدنية للادولة عن الاضرار الناجمة عن الارهاب في القانون





1. دستور جمهورية العراق الملغني لسنة 1970. 2. 2. دستور جهورية العراق النافذ لسنة 2005. 3. 4.




7.

8. رق ر (20) لسنة 2009 المعدل.

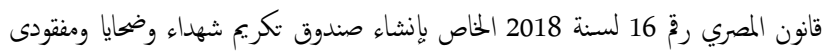
ومصابى العمليات الحربية والإرهابية والأمنية وأسرهم.
يجيوز تشكيل أكثر من محكمة في مركز المحافظة بناء على طلب من مجلس الوزراء

$$
\text { وموافقة مجلس القضاء الاعلى). }
$$

نقتزح تعديل المادة (9) قانون تعويض المتضررين جراء العمليات الحربية والاخطاء العسكرية والعمليات الارهابية رقز (20) لسنة 2009 المعدل من


أ. زيادة مبالغ التعويض المنصوص عليها في المادة (9/ أولاً و ثانياً و ثالثاً) وذلك لأن هذه المبالز لا تتناسب مع حجم الاضرار المشار إلها في هذه



ب. بشمول ذوي المققود والختطف أيضاً بمبالخ التعويض المنصوص عليها في

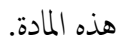

ندعو من المثرع العراقي إلى ضرورة إنشاء صندوق لتعويض أضرار الكوارث الطبيعية وغير الطبيعية وان يجدد ذمة مالية وشخصية معنوية مستقلة لنعويض ضحايا، كما فعلها المشرع الفرنسي بإصدار قانون (9) ايلول لسنة 1986 والمصري بإصدار قانون رق 16 لسنة 2018 الخاص بإنشاء صندوق تكريم شهداء وضحايا ومفقودى ومصابى العمليات الحربية والإرهابية والأمنية وأسرهم. من الضروري تشكيل عدة لجان فرعية في اقليم كوردستان ومحافظة نينوى وفتح لجان فرعية أخرى في المناطق المتنازع عليها وذلك لأستلام طلبات الضحايا من النزاعات المسلحة والإسراع في إنجاز المعاملات وتبسيط الإجراءات والابتعاد

$$
\text { عن الروتين والتعقيد. }
$$





1. أمد السعيد الزقرد، تعويض الاضرار الناشئة عن جرائم الارهاب، دار الجامعة الجديدة،


2.

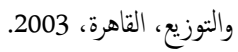
3. د. توفيق حسن فرج وعصام توفيق فرج، قواعد الإثبات في المواد المدنية والتجارية،




الاعمال الارهابية في القانون المصري والفرني، دار النيضة العربية، القاهرة، 2006.










Cass. Civ, 22 avril 1992, Bull. Civ., II, No. 131.

وقد جاء في هذا المكى ان المادة 706-3 لا تنص الم على تعويض الاضرار الناتجة من الإصابة الجسدية للشخص.

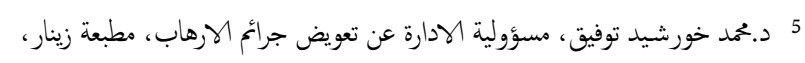



6 أمد السعيد الزقرد، تعويض الاضرار النانشئة عن جرائم الارهاب، دار الجامعة الجديدة،



7 (المصدر نفسه، ص213.

8 د. عاطف عبدالحميد حسن، الارهاب والمسؤولية المدنية (تعويض الاضرار الناشئة عن الاعمال

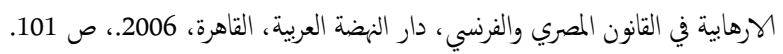







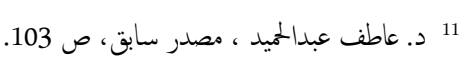

12 ممد عبدالواحد، ضحايا الارهاب بين أنظمة المسؤولية وأنظمة التعويضية، دار النهضة العربية،



Renoux (Th): L'indemnisation publique des victimes d'attentas, op. cit., ${ }^{13}$

P110, N165

نقلاً عن : د. عاطف عبدالمميد ، مصدر سابق، ص 101.

Renoux, P111. ${ }^{14}$

Cass civ., 3Janv.. 1951, s. 1951, I, P. $164 .{ }^{15}$

Cass civ., 15 nov. 1983, D. 1984, inf. Rap., P487. ${ }^{16}$

17 د. عاطف عبدالميد ، مصدر سابق، ص 106 ومابعدها.





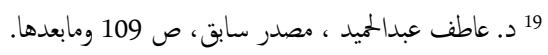

20

21 محمد عبد الواحد الجميلي ، ضحايا الإرهاب بين الأظمة المسؤولية وأنظمة التعويضية ، دار النهضة



22 د. عاطف عبدالمميد ، مصدر سابق، ص ص 110 ومابعدها.



$$
\text { د.عاطف عبدالميد، مصدر سابق، ص } 107 .
$$

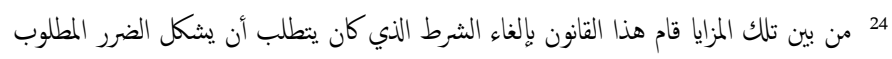







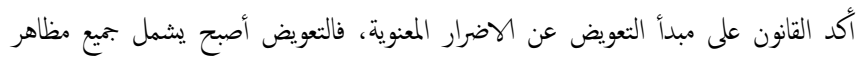

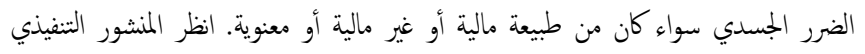







10. القانون الفرني رقّ 86-1020 في 9 أيلول لسنة 1986 المتعلق بكلفة الارهاب والمساس

بأمن الدولة.

11. قانون التأمين الاجتاعي والصحي الفرني الصادر في (23)كانون الثاني 1990.



4.5

1. Clara Sandoval and Miriam Boutique, ceasefire center for civilian rights, November 2017, p17 ceasefire.org.

2. Eric Mongelard, Corporate civil liability for violations of international humanitarian law, International review of the Red Cross, Volume 88, Number 863, 2006.

3. Gilat J. Bachar, Collateral Damages: Domestic Monetary Compensation for Civilians in Asymmetric Conflict, Chicago Journal of International Law, Volume 19 | Number 2, 2019.

4. Renoux (Th): L'indemnisation publique des victimes d'attentas, op. cit., P110, N165.

\section{5}

1. الأمانة العامة لمجلس الوزراء، اللجنة المركزية لتعويض المتضريين تناقش الآليات الجديدة



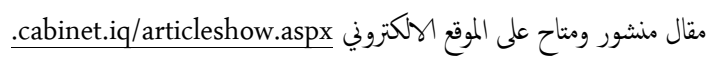

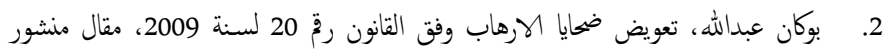

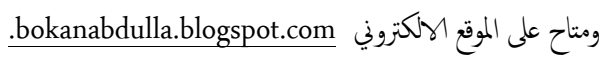

3. محمد حسن مرعي، تعويض ضحايا الإرهاب- دراسة قانونية في تعويض ضحايا الإرهاب في

العراق، مركز نون للدراسات الاستراتيجية، مقال منشور ومناح على الموقع اللكتروني

. nooncenter.org/ar/studies/12

4. منظمة مراقبة حقوق الإنسان، تفجيرات داعش جرائم ضد الإنسانية،" تعويض الضحايا



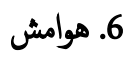

${ }^{1}$ Gilat J. Bachar, Collateral Damages: Domestic Monetary Compensation for Civilians in Asymmetric Conflict, Chicago Journal of International Law, Volume 19 | Number 2, 2019, p377.

$$
2 \text { تم إدخال هذا القانون ضمن قانون الإجراءات الجنائية الفرنسي من المادة (7377-3 حتى حتى المادة }
$$

3 احمد عبد اللطيف الفتي، الجاني والمجني عليه وحقوق ضحايا الجريمة، دار الفجر للنشر والتوزيع،

القاهرة، 2003، ص75.

4 أنظر الفقرة الوولى من المادة (3-706) من قانون الإجراءات الجنائية الفرني التي تنص على ما

\section{يلي:}

(Toute personne ayant subi un préjudice résultant de faits volontaires ou non qui présentent le caractère matériel d'une infraction peut obtenir la réparation intégrale des dommages qui résultent des atteintes à la personne,) 


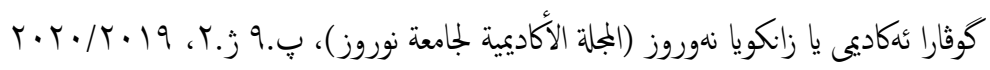

42

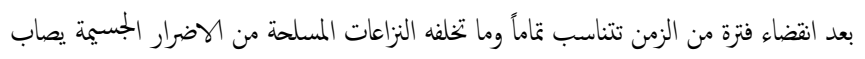






















2019/9/2 nooncenter.org/ar/studies/12

46

47 47 المادة (3) من قانون تعويض المتضررين جراء العمليات الحربية والأخطاء العسكرية والعمليات الارهابية رقٍ (20) لسنة 2009 المعدل.

48 حيث قامت هذه اللجنة إنشاء (دليل تعريني منصل) بالضوابط والاليات المتبعة في عملية



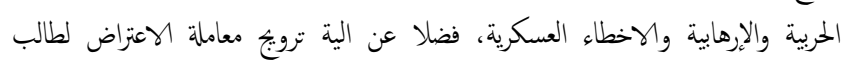








نهاية هذه الاطروحة.

49 منظمة مراقبة حقوق الإنسان، تفجيرات داعش جرائم ضد الإنسانية،" تعويض الضحايا المدنيين-

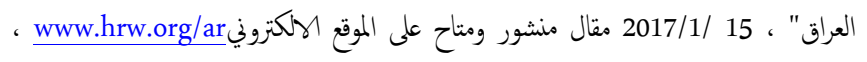

تاريخ الزيارة 2019/11/8.

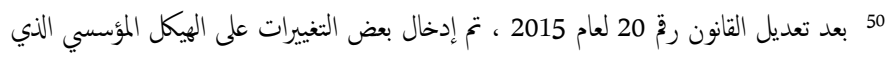

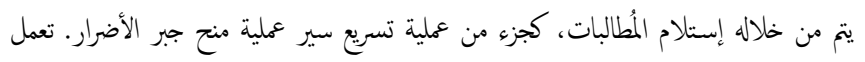











المسحلة الداخلية.

Clara Sandoval and Miriam Boutique, ceasefire center for civilian ${ }^{51}$ ceasefire.org. rights, November 2017, p17

52




.2019/8/31
25 وقد نص فيها على أنه (التضامن الاجتاعي هو الاساس الأول المجتمع ومضمونه ان يؤدي كل

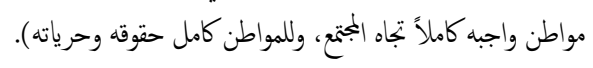









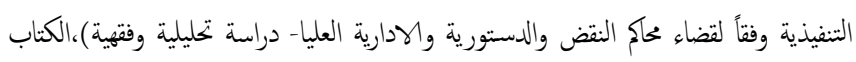





31 بوكان عبداله، تعويض ضحايا الارهاب وفق القانون رقّ 20 لسنة 2009 200د، مقال منشور ومناح

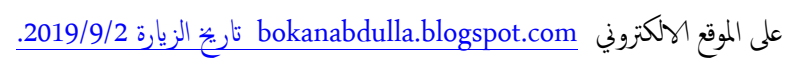
322





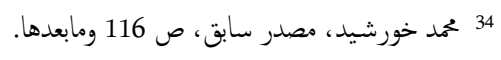
35 للمزيد من التفاصيل ينظر الوقائع العراقية العدد (4001) الصادر في 2005/7/19.

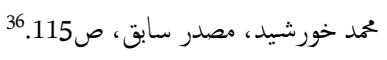

37 بوكان عبدالله، مصدر سابق.

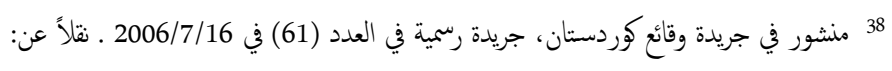



39 قانون تعويض المتضررين من جراء العمليات الحربية والأخطاء العسكرية والعمليات الورهابية رقز

(20) لسنة 2009 المعدل.

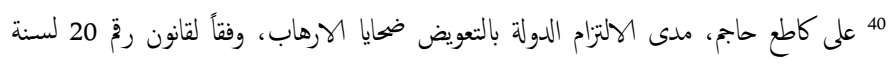















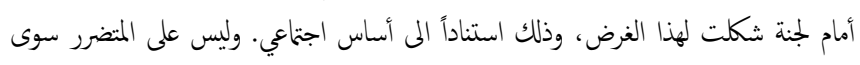













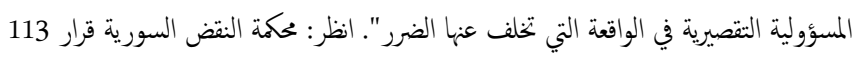

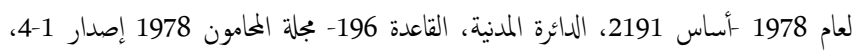
مرجعية حمورابي رق 1978 أساس 55438. 41 المادة (2) قانون تعويض المتضرين الروهابية رقٌ (20) لسنة 2009 المعدل. 




سادساً: يُستثى ذوو الشهاء من مسقط الرأس و أحكام قرار مجلس قيادة الثورة المُحل رقز (120) لسنة 1982 والتعليات الصادرة بوجبه.

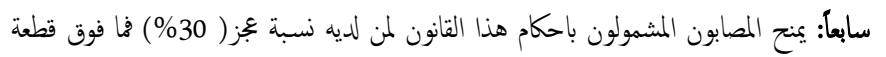




وفي حالة تعذر تنفيذ ماجاء في هذا البند يدفع لم فيها قيمها بسعر السوق السائد.









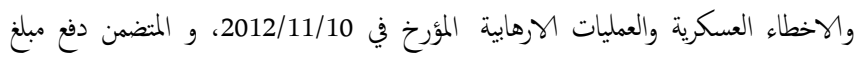



.2009

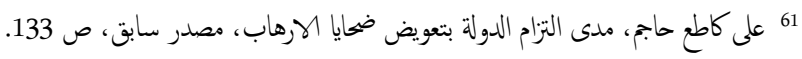








الصحفي، مصدر سابق، ص660.







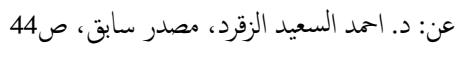



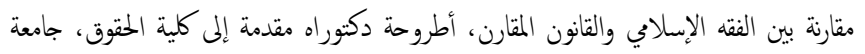

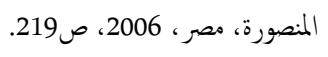$$
68 \text { على كاطع ، مصدر سابق، ص } 135 .
$$

(المب 69 المصدر نقسه، ص135.

70 المادة 132 من قانون الإثبات العراقي رقّ صدم 135 لسنة 1979 المعدل.





$$
72 \text { على كاطع، مصدر سابق، ص136. }
$$$$
73
$$

747 د. محمد جلال حسن الاتروشي، المسؤولية المدنية الناجمة عن عمليات نقل الدم، دار الحامد



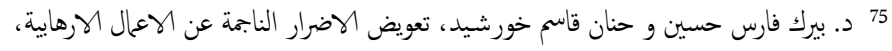


ص 488

76 في كولومبيا ، على سبيل المثال، على شركات النفط دفع مساهمة خاصة لمساعدة ضحايا النزاعات


جلمت هذه الضريبة للحكومة الكولومبية إيرادات إجالية قدرها 250 مليون دولار. نقلاً عن:
53 قرار اللجنة الفرعية في كربلاء للمتضررين من العمليات الحربية والأخطاء العسكرية والعمليات







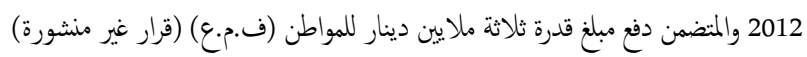

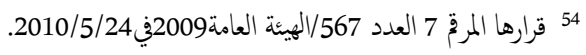
55 ينظرضص المادة (4) من قانون رق 20 لسنة 2009 حيث ترتبط اللجاندان المشار اليها بهذا القانون بالسلطة التنفيذية (المحافظة). 56 المادة (7- أولاً وثانياً) من قانون رقُ 20 لسنة 2009 المعدل.









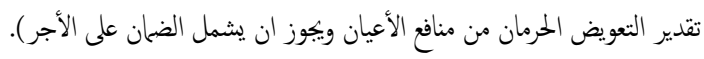













\section{على سبيل التعويض).}






بإعادة النظر في الثقدير).

58 أولاً :التعويضات النقدية: المادة (9) اولا: يعوض ذور الشهيد والمصاب بنسبة جزز من (75)



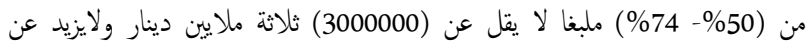



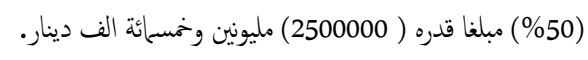

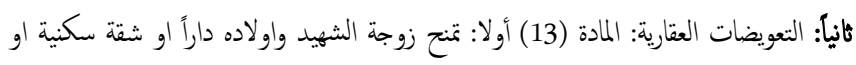





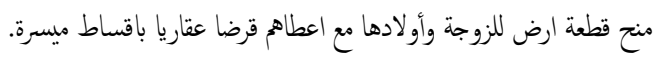


مقداره (50000000) خمسون مليون دينار.

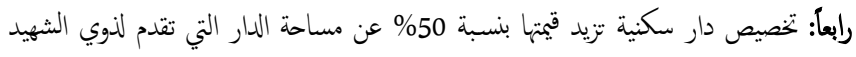

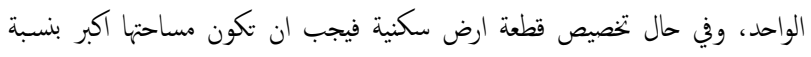

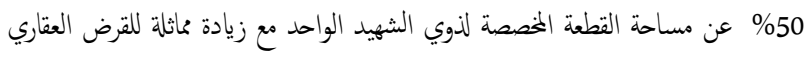
وتستحق هذه الزيادات لمرة واحدة.


الارض الممنوحة لهم وفق احكام هذا القنانون من الضرائب والرسوم الواردة في القوانين كافة. 




Eric Mongelard, Corporate civil liability for violations of international humanitarian law, International review of the Red Cross, Volume 88, Number 863, 2006, p666.

77 نص القانون 9 أيلول 1986 الفرنسي في المادة 5/9 منه ( إلزام جميع شركات التأمين بتعميم




.488

78 حيث حدد المشرع المصري من خلال المواد (9،8،) مصادر تمويل الصندوق، للمزيد من

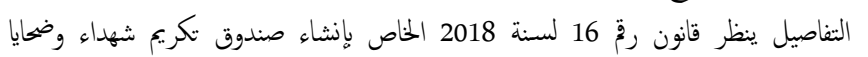

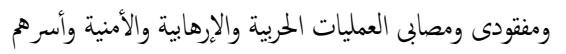

79 أن الصندوف تم انشاؤه وفقاً لقانون العدالة والسلام، الذي يتناول المسؤولية الجنائية لأفراد




والتبرعات. 